Article

\section{Unreasonable doubt: Politics and aesthetics in the crime novels of Horacio Vázquez Rial}

Ben Bollig

St. Catherine's College, University of Oxford, UK; benjamin.bollig@mod-langs.ox.ac.uk

How to Cite: Bollig, B. 'Unreasonable doubt: Politics and aesthetics in the crime novels of Horacio Vázquez Rial.' Radical Americas 3, 1 (2018): 1.

DOI: https://doi.org/10.14324/111.444.ra.2018.v3.1.001.

Acceptance date: 15 January 2018; Publication date: 23 July 2018

\section{Peer review:}

This article has been peer reviewed through the journal's standard double blind peer-review, where both the reviewers and authors are anonymised during review.

\section{Copyright:}

(c) 2018, Ben Bollig. This is an open access article distributed under the terms of the Creative Commons Attribution License (CC BY) 4.0 https://creativecommons.org/licenses/by/4.0/, which permits unrestricted use, distribution and reproduction in any medium, provided the original author and source are credited $\bullet$ DOI: https://doi.org/10.14324/111.444.ra.2018.v3.1.001.

\section{Open access:}

Radical Americas is a peer-reviewed open access journal.

\begin{abstract}
Horacio Vázquez Rial (Buenos Aires, 1947-Madrid, 2012) was an Argentine writer, historian and ex-militant in the Trotskyite Ejército Revolucionario del Pueblo (People's Revolutionary Army, or ERP). He left Argentina for Spain in the mid-1970s and became an outspoken critic of the Latin American left and in particular of the Kirchner and Fernández de Kirchner governments in the 2000s. He also penned a series of pioneering, neo-noir thrillers that return time and again to the violence of the mid- to late-1970s in Argentina. This paper draws on the work of Andrew Popper on crime fiction, Fredric Jameson on Raymond Chandler and Joel Black on the aesthetics of murder. It also responds to the work of Neil Larsen on another writer with a similar political trajectory, Mario Vargas Llosa, and answers a recent call from Jens Andermann for cultural studies practitioners to examine the ideology and the technique of right-wing works, in this case those dealing explicitly with the author's own former armed militancy.
\end{abstract}

Keywords: Vázquez Rial; crime; Argentina; literature; violence 


\section{Introduction}

There is a near standard chronology of crime fiction in Latin A merica that many of its histories recount. Implicit in this literary history is the possibility for the crime novel to espouse a broadly progressive, reformist or even socialist political agenda. From its earliest flowering as a genre, it is shaped by translation and parody, a result in part of features of the typical Latin American state. ${ }^{1}$ The forces of law and order, and more precisely the general public's trust in their competence and motives, essential for the 'classic' crime tale, are not sufficiently prevalent in much of the $r$ egion. The detective who collaborates with the law or the police detective him/herself do not make appealing or convincing protagonists. Jorge Luis Borges and others respond by both parodying the genre and importing and translating its most skilful exponents; the foreign setting resolves the problem of verisimilitude. Yet, if the classic crime fiction is negated by the political reality of Latin A merica, hardboiled fictions (the 'novela negra') and variants such as the neo-noir emerge, better suited to the region and its readership. Osvaldo Soriano, Paco Ignacio Taibo II, Leonardo Padura Fuentes, Mempo Giardinelli, Guillermo Saccomanno and Claudia Piñeiro, drawing on more recent trends in Anglo-American crime fiction, have crafted fictions that combine believable $\mathrm{n}$ arratives, compelling m ysteries a nd incisive social critique. ${ }^{2}$ Soriano's No habrá más penas ni olvido (1978) reworked the 'tough' fiction of Dashiell Hammett to criticise the lurch to the right of Peronism in the early 1970s, having earlier sent up the genre, portraying a washed-up Philip Marlowe, in Triste, solitario y final ( 1973). Taibo c o-authored a novel with the neo-Zapatista revolutionary Subcomandante Marcos and his works are open in their criticisms of political corruption under Mexico's PRI government. More recently, the so-called narconovela as practiced by Elmer Mendoza, has used the police procedural for acid social commentary on the state-crime nexus in the north of the country. ${ }^{3}$

Andrew Pepper's recent study of the politics of the crime genre acknowledges the 'difficulty of incorporating radical politics' into the form ${ }^{4}$ (p. vii). He sketches the competing commercial and political imperatives often at work in crime novels and questions whether practitioners can 'have their cake and eat it' (p. vii). But he also argues that the chronology of crime fiction needs to be reconsidered. The apolitical classic crime story - the world of ratiocinative detectives and later the 'cosy' village green murder is not the model, but rather a brief interlude. He states that 'the impetus to politicise and popularise the writing of crime as fiction has a much longer historical lineage and a much broader geographical trajectory' (p. viii) than the standard narrative, from Poe to Doyle to Hammett, or foundation, from classic to hardboiled.

Pepper's wider point is a sociological one and here his argument becomes pertinent for those working on Latin America: 'The development of crime fiction as a genre is bound up with the consolidation of the modern, bureaucratic state' (1). What we find in crime fiction is something close to an account of the state and its contradictions: the state as it takes on control of the justice system and a state that is at once 'necessary for the creation and maintenance of collective life and central to the reproduction of entrenched socio-economic inequalities' (2) - the latter, of course, leading often to crime.

Pepper is aware of the limited scope of his study and, in part, the aim of this article is to follow some of the directions he indicates for further analysis, what he calls the "expanded historical and geographical frame' needed to deal with crime. He admits that he has overlooked Latin America: crime fiction there 'is better able or more willing to explore the brutalities and violence of state power than US or European examples because right the way across Latin America people arguably regard and have always regarded, state violence as the norm rather than as an exception' (249). Latin American countries are important for another reason: Pepper asks himself, in a chapter on contemporary crime fiction, 'What if the state, challenged by other bodies, is unable to exercise its monopoly over the use of physical force?' (208). In Mexican narconovelas or in the context of armed insurrections, this question is very relevant. He writes of the emergence of 'parapolitics' alongside neoliberal governance, in the context of a 'crisis of sovereignty' (209). States may engage in 'extra-legal violence' and this violence can 'spiral out of control' (210).

In Pepper's volume, Borges is not mentioned, although he is in good company, as Pepper states that he prefers Hammett to Chandler, while James Ellroy, a Tory outlier in Pepper's cartography, is absent, 
except in a footnote. This is, in part, related to another political point: 'While right-wing crime novelists are by no means unheard of (...) the majority of the crime writers here, at least in the twentieth century, would identify with the left, albeit in complicated and often disaffected ways' (11 note 38).

Horacio Vázquez Rial ${ }^{5}$ (Buenos Aires, 1947-Madrid, 2012) is a writer who, with difficulty, fits the above pattern. A member of the Argentine Communist Party as a teenager in the 1960s, he became a Trotskyist in the mid-1960s and in 1968 joined the Partido Revolucionario de los Trabajadores (PRT). When the PRT split, Vázquez Rial joined the more militant PRT-El Combatiente faction, led by Mario Roberto Santucho. From there, he joined the Ejército Revolucionario del Pueblo (People's Revolutionary Army or ERP), in particular the 22 de agosto branch, under J. Fernández Palmeiro, who engaged in various acts of urban terrorism, in particular extortive kidnappings; Vázquez Rial referred to this period of his militancy as that of a 'trotskista armado.' Against the backdrop of escalating violence between the armed left and military and paramilitary forces in Argentina, he left for Spain in the mid-1970s. ${ }^{6}$

Having trained as a historian in Spain, ${ }^{7}$ in the 2000s Vázquez Rial became an outspoken critic of the Latin American left and in particular of the Kirchner and Fernández de Kirchner governments, writing frequently for the online paper Libertad digital. Vázquez Rial defined himself during this time as an ex-leftist and a liberal. As examples of some of the positions he adopted, one might cite his 2005 article which includes the discredited claim that Hezbollah had set up operations in Latin American with the blessing of left-wing governments in the region (107) or his strident attack on multiculturalism. ${ }^{8}$ In a 2009 article, he blamed Peronism for the hyper-inflation of the 1980s and spoke of Peronism's (and especially right-wing Peronism's) 'espíritu policial mafioso, que es lo característico del país desde hace décadas.' Elsewhere, Vázquez Rial refers to the Kirchners' policies of reparations to victims of the dictatorship's repression as 'un gran negocio político de victimotecnia', ${ }^{9}$ accuses Hebe Bonafina, a founder of the human rights organisation Madres de la Plaza de Mayo, of anti-Semitism, ${ }^{9}$ and calls Néstor Kirchner Argentina's worst ever elected president, with racist gibes thrown at the latter and Hugo Chávez along the way. ${ }^{10}$ In the 1990s and 2000s, he would express his admiration for the conservative Spanish premier José María Aznar as well as his support for the war against Iraq. Even an otherwise favourable review of his polemic La izquierda reaccionaria, which approves of his 'dardos contra el multiculturalismo', cannot avoid remarking on his 'páginas panfletarias' and his misrepresentation of Islam. ${ }^{11}$

This trajectory is far from unique, traced as it has been in one variant or another by writers as different as Mario Vargas Llosa and Martín Caparrós. Yet, Vázquez Rial's notable contribution is to have produced, starting in the 1980s, a series of brutal, compelling, neo-noir thrillers that return time and again to the violence of the mid- to late-1970s in Argentina. His telegraphic, paratactic style emerges alongside international neo-noir writers such as James Ellroy and David Peace, and goes a step beyond contemporary and recent works by Giardinelli and Soriano in terms of violence and stylistic innovation. What, the critic finds herself asking, is the relationship between an eye-catching and in many respects experimental style, and a reactionary politics? Picking up on Pepper's characterisation above, Vázquez Rial relates to the left in a 'complicated and disaffected' way. As late as 1980, Vázquez Rial claimed, he continued to see himself as a Trotskyite; ${ }^{12}$ yet, having quit one left-revolutionary group, he dedicated the last decade or more of his life to mordant critiques of the actually existing Latin American left, in particular Kirchnerismo. Ernst Mandel earlier pondered the politics of the crime genre, noting the shift from an integrative (i.e., conservative) to a disintegrative (i.e., critical) function in the genre. ${ }^{13} \mathrm{He}$ gave cases of particular authors who had followed this path, for example Graham Greene who, in his novels on Latin American themes, from The Power and the Glory (1940) to The Honorary Consul (1973), shifted from conservatism to anti-imperialism (123). Vázquez Rial follows the opposite path in his life and works.

This study also responds to a recent call from Jens Andermann for cultural studies practitioners to examine the ideology and, implicitly, the technique, of right-wing works: the 'particular genre of political fantasy literature' that emerged in the run-up to and wake of the 2015 presidential elections in Argentina ${ }^{14}$ (p. 13). Andermann is talking about investigative journalism, but it is fair to extend this to works that, although novelistic, base themselves on something like a version of the recent Argentine past 
and whose author missed few opportunities to state his credentials as a historian. A further precedent for this investigation can be found in the work of Neil Larsen, writing about Mario Vargas Llosa. ${ }^{15}$ explored the contrast between the political certainty of his columns and memoirs, in particular El pez en el agua (1993) and the doubts he can entertain in fiction. In his article on Vargas Llosa, ${ }^{15}$ observed that the Peruvian's lauding of individual freedom came at the cost of ignorance of the very real lack of freedom for millions of Latin Americans. Thinking of the later career of Vargas Llosa as a political commentator, one might also add another similarity with Vázquez Rial: namely, pouring scorn on any politician who attempted to remedy that lack of freedom. Might we credit Vázquez Rial with what Neil Larsen observed with reference to Vargas Llosa and the striking gap between the latter's explicit ideology and the political implications of several of his books: 'an artistic integrity that, faced with the choice between an allegorical fiat or a fetishised 'technique' and a story that has begun to tell itself, almost invariably chooses the latter. This is, after all, the story that will sooner or later sweep away the ideologue himself ${ }^{15}$ (p. 177)?

Little academic attention has been paid to Vázquez Rial's novels. In part, this is because of his intermediate status: Argentine-born, writing mainly about Argentina, but published in Spain and with what he called a 'fundamentally Spanish' audience ${ }^{16}$ (p. 193). His books are also not always especially palatable. Firstly, they are extremely violent, featuring numerous murders, shootouts, fights and scenes of torture. This goes for both his novels dealing with recent history and those set further in the past. Frontera sur (1994) depicts the brutal treatment of prostitutes in fin du siècle Buenos Aires and includes a series of infanticides. The novels are also full of sex. Within the first 30 pages of Territorios vigilados (first published 1988), the protagonist, Joan Romeu, has slept with a former lover and then her daughter. In La capital del olvido ${ }^{17}$ Romeu again takes time out from investigating the traffic of babies during the 'proceso' to energetically and repeatedly go to bed with one of the principal suspects. Leitmotifs related to sex also appear, for example female characters who appear naked except for high heels: Malena in Historia del Triste ${ }^{18}$ (p. 87) and La Bruja Ofelia in Territorios vigilados ${ }^{19}$ (p. 95). There is little stylistic change between descriptions of sex and violence in the novels; both activities punctuate an episodic structure in which we follow the protagonist in his investigations, unravelling webs of evil through contacts, insight and action. The exception within our relatively small corpus is La libertad de Italia (1987), in which the protagonist, Arellano, moves inexorably towards, not the solution, but his own death, alternating the fatal journey with alcohol, sex and (for Arellano and the narrator, justified) murders along the way. One further and quite striking, aspect of the novels is the presentation of alcohol. Characters in Vázquez Rial's novels drink huge quantities of it, at all times of the day. Gin is the poison of preference (in La capital, Romeu allows himself a brandy or two) and having a full bottle ready at hand is as important as having weapons and a plan before the many violent confrontations that occur in these works. It is hard to escape the conclusion that many of Vázquez Rial's characters are, throughout the novels, permanently drunk.

There is, then, much of the Grand Guignol about Vázquez Rial's work or, as Joel Black puts it, an attempt to take 'crime to a theatrical extreme' ${ }^{20}$ (p. 196). By using a protagonist who, in the course of an investigation or an attempt at self-preservation, is obliged to fight and kill, repeatedly, Vázquez Rial explores 'the artistic possibilities involved in portraying homicide from the murderer's point of view' (61). These, then, are works that often 'present murder from an aesthetic rather than a moral, psychological or philosophical perspective' (9). The same can be said of the other strong sensations aroused in these works, not least by the portrayal of sex. Pepper, describing Pierre Lemaitre's brutal thriller Alex (2013), assesses the risks of graphically violent crime novels. 'Without logic or explanation, the violence becomes not just horrific but almost unreadable.' Novels thus run the risk 'of reducing the violence to an albeit horrific banality' ${ }^{4}$ (p. 228).

One should note that it is difficult to take Vázquez Rial's novels in isolation. Characters reappear from one novel to the next, novels pick up the plot of earlier works, and sections of some books are narrated by other characters; the author claimed that his first three novels are narrated by Reyles, a character found in later works. As Young puts it, we have 'a network of complementary narratives in which the representation of the act of narration, the process of elaboration of the text itself and the 
passage of the story from speaker to listener is as significant as the content of the story itself ${ }^{21}$ (p. 510). Our focus here is on three early novels, Historia del Triste, La libertad de Italia (1987) and Territorios vigilados, with passing reference to other, especially more recent, works. Libertad and Territorios are closely related; Historia overlaps with them in theme and setting, but with a different cast. These are novels that date from around the time of the author's turn to the right - after his break with the armed left and Trotskyism, but before his explicit adoption of a self-defined liberal identity and political stances - on US and European foreign policy, on Islam, on multiculturalism, on post-dictatorship memory and justice - closely allied with the Latin American political right. As such, they point at the position he would adopt and show the bases on which it is constructed. In all three, Vázquez Rial chooses to focus on some of the key political moments of recent Argentine history. This blurring of fact and fiction - or perhaps, more accurately, the referencing of real events in fiction - continues throughout his work. In $\mathrm{La}$ capital del olvido, as well as the general setting against the backdrop of the legacy of the dictatorship, we read references to real-life murder cases, including those of Oriel Briant ${ }^{17}$ (p. 162) and the Puccio 'clan' (160), who committed extortive kidnaps and murders in the 1980s. Vázquez Rial's novels are compelling works of crime fiction, a revealing case study for the politics of this atypical yet pioneering writer and illustrative of and a forerunner to recent tendencies in popular right-wing fiction.

\section{Historia del Triste}

Despite its relatively modest length (a little more than 200 pages in most editions), Historia del Triste is an ambitious novel. It tells the story of Cristóbal Artola, the 'sad man' of the title, a child from the southern fringes of Buenos Aires, abandoned by his father, who moves from billiard hall shark to petty enforcer, to outlaw, against the backdrop of mid-century Argentina - from the first Peronism to the 1976 coup. Like the 'middling characters' in György Lukács' study of the historical novel or Forrest Gump in the role made famous by Tom Hanks, this allows a figure with little or no education to witness and comment on some of the most important events in Argentina's recent history: the lying in state of Eva Perón, the coup against her husband, President Juan Domingo Perón, the kidnap of General Aramburu by Montoneros, the death of Perón himself, and the development of clandestine centres for torture and disappearance. In 1965, he sees Che Guevara riding a horse through the streets of Buenos Aires. As the narration states, 'le correspondió al Triste el dudoso honor de ser testigo' ${ }^{18}$ (p. 197) to key moments in Argentina's recent past.

The novel's ambition is marked in other ways. Each chapter has an epigraph. Many of the sources are popular and Argentine, in particular tangos from Homero Manzi and Enrique Santos Discépolo, for example. Others are literary and contemporary, such as Borges and Juan Gelman, others come from the history of Argentine letters (e.g., Santos Vega, José Mármol), and there are foreign sources, including César Vallejo. Often, these are writers with a strong political connection - Gelman, of course and also Leopoldo Marechal, the left-wing, Catholic, Peronist author of Adán Buenosayres.

Historia del Triste seems, quite consciously in its opening chapters, to rewrite the early twentieth-century Argentine author Roberto Arlt's semi-autobiographical novel El juguete rabioso (1926). Indeed, even the protagonist's name, Artola, sounds like a reference to the earlier writer. The opening chapters, as el Triste moves from petty crime, to playing billiards for money, to organised criminality, are a successful version of the series of failures experienced by Silvio Astier in Arlt's work. Artola's absent father is referred to as a 'rufián' (pimp), 'quizá melancólico'18 (p. 20), another overt reference to Arlt and his diptych Los siete locos (1929) and Los lanzallamas (1931), which feature a character called 'The Melancholy Pimp.' Also, the world of shady plots, crypto-fascist conspirators and pseudo-revolutionary violence, is very much that of Arlt's two most political novels.

Other literary references abound. Early in the novel, mention is made of el Triste's friend 'Fierro' 18 (p. 47), a clear echo of Argentina's national epic poem, The Gaucho Martín Fierro. As with Albert Camus' Mersault, his first violent crime is committed after his mother's death, when he slices the hand of the fruit seller from whom he has just stolen some oranges (24-25). In his encounter with his father, the pimp Manuel Lema, whose name is the last words on his mother's, Rosario Artola, lips, one hears an echo of Juan Rulfo's Pedro Páramo (1955). While Pedro Páramo collapses in or like, a heap of stones 
at the end of the Mexican novel, Vázquez Rial's novel strongly hints that Lema is murdered by his son, el Triste ${ }^{18}$ (p. 100). Chapter 5 is called 'Segundo sello', seemingly a biblical reference to the book of Revelation, in which the opening of the second seal releases the red horse and with it takes away peace from the earth.

Historia del Triste is also marked by the distinctive prose style that several of Vázquez Rial's crime novels employ. Young, referring to another novel (Los últimos tiempos) writes of his 'clipped, Hemingwayesque style (...) reminiscent of the hard-boiled tradition of North American (sic) detective fiction, ${ }^{21}$ (p. 508). Eschewing as far as possible capital letters or full stops (whose expected place is often occupied by colons), chapters are divided into large blocks of text, often stretching over several pages. The effect is relentless, fast-paced and, in violent sections (particularly the torture scenes towards the end of the novel), highly visceral. There is also a tendency towards over-narration, a feature one associates with the hard-boiled and in particular more florid passages from Raymond Chandler. There is a reference, for example, to 'el bolso siniestro de sus herramientas' ${ }^{18}$ (p. 143) or this passage from the start of chapter 16:

si el oficio dado por la vida a Cristóbal Artola se desempeñaba en los dominios de la muerte, no siempre su obra debía culminar en la forzosa separación de almas y cuerpos (145).

As well as the hyperbaton ('no siempre su obra') and the periphrasis, there are the elevated tone and register, at odds with the crude reality - the life of a hired thug and killer - being described. The novel also adopts a strange halfway idiom, between Argentine and Spanish usage. Characters use abundant slang in their speech, but the narration is standard, often quite elevated in register and not marked as Argentine; one notes the use of 'coger' in its non-sexual sense (24), very much not Argentine usage.

Key, too, in this novel is its use of prolepsis or the flash-forward: repeated future and conditional tense verbs, as well as predictions from the narrator, stress the inevitability of events, that narration is being conducted from a distant, stable and secure point. Very early in the novel, we learn of Artola's mother's death and funeral, but the full details do not come for another few pages. The novel's third paragraph already looks ahead to the face of el Triste at the time of his death, the sum of the scars that he bears $^{18}$ (p. 19).

On top of his presence at key events in national history, el Triste plays a role in less widely known occurrences: the kidnap of the union activist Felipe Vallese, ${ }^{22}$ the murder of the medical student Daniel Grimbank during demonstrations in 1965, and 'The Night of the Long Sticks', a violent attack on the University of Buenos Aires. Artola also kills a student leader by the name of Starobinsky (130) or Stranobinksy (136). Rodolfo Walsh makes a brief appearance in the novel (174), as does Padre Mujica (199). When dealing with one of the more famous events, the narrator offers different perspectives. In a section alluding to the kidnapping and death of the former de facto President General Aramburu, we read three versions, blaming either Montoneros, the military or the far right (145-47). ${ }^{23}$ David William Foster states that 'Triste, neither a hero nor an antihero of this history, is yet both its (historical fact's) agent as an enforcer and an executor of the designs of repression and a witness to a process whose complexity few have been able to grasp in all its ambiguous and contradictory details' ${ }^{24}$ Foster seems to overlook a very specific claim made in the novel, one which Vázquez Rial himself repeated elsewhere, namely, that Montoneros was the product of the forces of oppression in Argentina, part of a plot to agglomerate, weaken and then destroy the left in Argentina. What links all these events is a hidden thread, namely, that Montoneros was in essence a product of the far right masquerading as the Peronist popular left wing. In an interview cited by Noya and Somalo ${ }^{12}$, Vázquez Rial notes a key difference between the ERP, to which he belonged in the late 1960s and Montoneros: 'Los que tenían armas eran los Montoneros. El ERP nunca tuvo armas de verdad, salvo las que proporcionó Cuba a la guerrilla rural en la provincia de Tucumán. (...) Y lo que hubiera sido terrorismo, la guerrilla urbana, en realidad fue virtud de Montoneros. Lo que hizo ERP fue asaltar cuarteles.' It also engaged in kidnappings and robberies in order to 'financiar la revolución'; Vázquez Rial claimed (or perhaps admitted) to have been involved in two such kidnappings. 
For Liberman $\operatorname{Isod}^{25}$ (p. 231), Historia del Triste plays with the double meaning of historia, as story (i.e., fiction) and history (i.e., fact). ${ }^{26}$ The novel thus tells two tales. One is about el Triste, who rises unwittingly from petty crime to the para-police repressive apparatus. The other is a story of the Argentine working classes and political struggle in that country in the short twentieth century. In the case of the latter, the narration of the novel is worthy of further comment. Several chapters include or begin with relatively lengthy digressions from the details of el Triste's life story to tell its context: psychological differences between the social classes ${ }^{18}$ (pp. 22-23), rural-urban migration in Buenos Aires (29), and a great deal of historical background. The narrator knows things that no character in the novel could know, at both the personal and the national level. We read, for example, of 'la construcción de los que llegarían a ser trescientos cuarenta campos de tormento, exterminio, concentración, en toda la república' ${ }^{18}$ (p. 203). Artola's last words, 'Patria o Muerte', the narrator also tells us, were heard by no one (227). The historical sequences mix more or less accepted historical facts - the bombing of the Plaza de Mayo by the Argentine Air Force in 1955, the mass demonstrations of grief at Evita Perón's death with what the novel itself calls 'rumores' and 'hablillas', for example over the macabre fate of striking railworkers under President Perón (35-36). That is to say that we experience events close at hand, via el Triste, but also are informed about national politics.

There is overlap, though, between the different levels, the story of el Triste and the history to which he, in small part, contributes. El Triste's erstwhile handler, then partner in crime, the priest Chaves, who enters the world of the para-police, proffers theories about politics in Argentina. As Artola's worldview expands, he offers his own theories. The men conclude that, throughout their criminal career in clandestine political actions, Perón has been their secret paymaster (199). El Triste agrees. Their retirement plan is to carry out an extortive kidnap under the guise of a dissident montonero commando. Chaves and el Triste have already acted in the name of Montoneros, in their involvement in the death of General Aramburu. Chaves suggests that Montoneros is not the popular Peronist group that it seems: 'detrás de todo eso (Montonero activity) debe de haber gente que nosotros conocemos, que alguna vez nos pagó por nuestro trabajo: jerarquía militar, disciplina militar, nazi.' The group offers a useful cover: 'los montoneros, a veces, somos nosotros' (204).

The theory offered by this novel, then, is one often found in criticisms of armed left militancy in Argentina, both from the right and from the left, namely, that Montoneros was either formed or severely infiltrated by rightist, pro-coup elements from the military. In an interview, in Galician, with Xesús González Gómez, Vázquez Rial states:

Montoneros era unha onganización creada polos servicios de intelixencia e que funcionou perfectamente como factor aglutinante e liquidador da maior parte da esquerda. Os exemplos pódense multiplicar ata o infinito: Italia, cos comandos autónomos; Irlanda, o IRA e o apoio do Vaticano $^{16}$ (p. 185).

Vázquez Rial's theory about Montoneros is at least controversial. Montoneros was an armed revolutionary group that emerged from a fusion of several militant organisations, some Peronist, some Trotskyite, in the late 1960s-early 1970s. At the height of its powers, it could claim tens, even hundreds of thousands of members. Its popularity waned after it entered into open conflict with Perón himself and the group entered into clandestinity around the time of the 1976 coup d'état, with most of its leaders heading into exile and many of its grassroots activists and militants falling into the clutches of the repressive apparatus. Gillespie ${ }^{27}$, in his study of the group, entertains the possibility that Mario Firmenich, its head, was a military plant. He also notes Juan Gelman's and others' criticism of the group for its militarism. ${ }^{27}$ Even those favourably disposed towards the group, such as José Amorín, a founder member, are critical of the confrontational, anti-Peronist military turn that it took, exemplified in the murder of the union leader José Ignacio Rucci in $1973 .{ }^{28}$

The sociologist Pilar Calveiro, in her volume Politica $y / o$ violencia ${ }^{29}$, critically analyses the ideology of the armed left. She too notes that Firmenich has been widely accused of being an infiltrator. His political trajectory takes in a background in right-wing Catholic activism, then the Peronist armed left and finally militarised militancy, for a number of years proselytised from overseas. Calveiro disagrees 
with what she sees as a conspiracy theory. After tracing the militarist and totalitarian logic of the Argentine armed forces, the shift to the right of Peronism and its union bureaucracy in the 70s, she identifies the impoverished Clausewitzian logic of certain armed groups and their leaders, who came to mimic the very armed forces they were fighting. In some ways, Calveiro's critique is far stronger than simply saying that Firmenich or others were traitors or double agents: she argues that the decisions he and those close to him made were so bad and the consequences for the many rank-and-file militants and their friends and families so lamentably predictable, no double agent would have dared to make them. This does not support the theory espoused by Vázquez Rial and voiced by his characters.

In the preface to Historia, Vázquez Rial spoke of his desire to write of 'los otros', in particular in relation to his own relatively middle-class upbringing and subsequent political militancy in anarchist and left-wing groups. Artola's name is an anagram of 'la otra' (the other - feminine). It is a novel, the author claims, marked by a shift from political certainty - that the author was on the side of history and progress and the protagonist on the other - to doubt: of both his own role and that of the protagonist. Where they meet, however, is on the question of morality, of honour within violence. In particular, Vázquez Rial cites his rejection of torture or violence for its own $\operatorname{sake}^{18}$ (pp. 9-10). It is a curious thesis, to say the least. Of the many things Montoneros has been accused of, the use of torture is generally not one of them. This is a subtlety explored in Carlos Gamerro's novels La aventura de los bustos de Eva $a^{30}$ and Un yuppie en la columna del Che Guevara ${ }^{31}$. Vázquez Rial's theory relies on erasing the distinction between Montoneros and the security services against which they saw themselves fighting. Historia del Triste's blurb talks of Artola's honour code or 'código de honor.' As the novel nears its conclusion and we follow his development as a more politically aware and increasingly moral character, we read of his personal commandments. These include 'no torturarás', as well as more specific prohibitions of some of the more horrific actions that he has witnessed or understood that are set to take place (219-20). As Foster puts it, 'Triste witnesses the organization, refinement and increasingly efficient implementation of an underworld of politically motivated terrorist operations that constitute the true reference point for contemporary Argentine social history'. ${ }^{24}$ This informs his morality, it seems for the better.

This is the conclusion of a steady process of humanisation for the protagonist. El Triste's worldview is simplistic and, in his early years as an enforcer, highly prejudiced. It consists of a confused mix of Peronism, nationalism and anti-communism. El Triste justifies his violent actions as part of a war against the same enemies that Perón - whom his mother idolatrised - fought: 'judíos, comunistas, terroristas, maricones' ${ }^{\prime 18}$ (p. 71). The word 'burgués' is unclear to him but still inspires anger. Initially, his crimes are gratuitous (the attack on the fruit seller), born of frustration and pain. Later, they are motivated purely by money, but, increasingly, they are underpinned by his morals: killing face to face, not killing indiscriminately, not inflicting pain for its own sake. He refuses to fire into the crowds during the 1965 demonstrations; later, he refuses to shoot at the public at Ezeiza airport, during the massacre that accompanied Perón's return in 1972. There, he says to Chaves, in a gesture that shows a return to his popular and even Peronist origins, 'Sí, vamos con la gente' (174). Liberman Isod notes the conflicting emotions that el Triste might inspire in the reader, from hatred to tenderness, to a 'molesta piedad $^{25}$ (p. 232). El Triste, a multiple murderer, can be described with the words of Joel Black as a 'social rebel' 20 (p. 190), rather than a political actor. The novel, like the later work Territorios vigilados, makes a cult of bravery: no one is condemned in these novels more strongly than those neighbours and bystanders who pass by, ignore or keep silent the acts of violence that occur around them. One of Vázquez Rial's many attacks on Néstor Kirchner focussed on the latter's 'reivindicación de un terrorismo (i.e., left/student Peronism) en el cual ni siquiera había tenido el valor de militar' (2010).

David William Foster, reviewing the novel, writes of el Triste as a 'picaresque survivor' who does not survive. ${ }^{24} \mathrm{He}$ echoes here Fredric Jameson's words on the detective genre: 'The equivalent is the picaresque novel, where a single character moves from one background to another' ${ }^{32}$ (p. 7). Foster sees Artola as a representative of the "members of the marginal class (who) have been recruited to serve as para-police elements in the suppression of individuals and organizations whose goal is to bring about forms of proletarian social revolution.' He is 'an enforcer in a cloudy chain of command who is ordered 
to commit various acts of violence in the name of beliefs which hold no interest for him but whose resources allow him to survive'. ${ }^{24}$

A form of anguished witnessing takes place in the two visits el Triste makes - first as an ally, then as a victim - to a clandestine detention and torture centre. His first contact with the emerging repressive apparatus takes place in early 1976, that is to say before the coup and at the hands of the forces that emerged during María Estela 'Isabelita' Perón's presidency, under the guidance of her advisor José López Rega and which would achieve their full horror with the arrival of military rule. He dies on 24 March 1976, the very day of the golpe de estado. If earlier in the novel we have witnessed violence in a voyeuristic fashion, in the visits to the hell of para-state repression, something different occurs. It is, in Joel Black's words, 'altogether different from the conventional masculine gaze which is voyeuristically directed at an arousing spectacle or desirable object ${ }^{20}$ (p. 66); this is not an example of 'horrific banality' (228). Liberman Isod argues that el Triste 'acabará sus días sumido en el más profundo escepticismo'25 (p. 233). However, he overlooks his last act of rebellion: to run from the forces of oppression, shouting 'Viva Perón', before dying with Montoneros' slogan 'Patria o muerte' on his lips $^{18}$ (p. 227). This underscores both el Triste's moral code and the narrator's omniscience.

The novel ends with a curious epilogue, in which a narrator critiques two quotations from poems by Juan Gelman, 'Esperan' (from Si dulcemente, 1980) and 'Abrigos' (from Hechos y relaciones, 1971-73). The last words of the novel, seemingly a challenge to Gelman's more positive, even optimistic assessment of the state of the contemporary revolutionary left, are, '¿qué triunfo?'18 (p. 228). The choice of Gelman is revealing: the poet was a member of Montoneros but left the organization, penning an open letter in criticism of what he saw as a misguided, even suicidal strategy of 'counter-attack' against the junta. But in his poetry of the 1980s and beyond, Gelman continued to express hope for the possibilities of revolution in Argentina. ${ }^{33}$ The novel's epilogue underscores Vázquez Rial's antipathy towards Montoneros and a general pessimism about left politics in the country. El Triste's story suggests that many of the militant and armed left were either dupes or sociopaths.

\section{La Libertad de Italia}

La libertad de Italia, also from 1987, is a novel that explores further Vázquez Rial's misgivings about the armed left in Argentina. It tells the story of the final few days of Miguel Arellano, a member of what is called throughout the novel 'la orga' (the organisation). The incident draws on one from Vázquez Rial's own experience in the ERP, when he and the real-life Arellano were left guarding the proceeds from an extortive kidnapping. ${ }^{12}$ In the novel, entrusted with this large sum of money, the fictional Arellano, already disenchanted with his life as a militant, abandons his comrades and escapes to Europe, seeking the 'freedom of Italy' of the title, in the company of his girlfriend, Marga. The quotation is from Cervantes' novela ejemplar or exemplary story, 'El licenciado Vidriera', (1613), a work cited in an epigraph. Vázquez Rial's quotation is at least ironic: '. . . las alabanzas en el cielo a la vida libre del soldado, y la libertad de Italia...'34 (p. 9). In Cervantes' tale, the line refers to the words of an army captain who is attempting to recruit a young man, Tomás Rodaja, to a life of soldiering. Cervantes' narrator notes the Captain's omissions: 'pero no le dijo nada del frío de las centinelas, del peligro de los asaltos, del espanto de las batallas, de la hambre de los cercos, de la ruina de las minas, con otras cosas deste jaez' ${ }^{35}$ Rodaja is a well-educated man of humble origins, who makes a successful career out of soldiering before returning to his studies, where he wins fame and renown despite coming to believe himself, as a result of poisoning, to be made of glass. Restored to his sanity, Rodaja/Vidriera struggles to cope with his new-found fame and returns to the army, finding his death in battle in Flanders. Vázquez Rial's point is clear: the glamour of soldiering is attractive but ultimately fatal.

Alongside the line from Cervantes, one finds a long quotation from Roberto Arlt's Los siete locos, in which a character known as the Astrologer explains to the protagonist, Remo Erdosain, his plans for a secret society based on the Ku Klux Klan, that will come to rule Argentina. The Astrologer cannot decide if his society should be Bolshevik or fascist and says that he is inclined towards an "ensalada rusa que ni Dios entienda'. ${ }^{36}$ The speech occurs during a scene that unites three important characters in the novel: Erdosain, who is desperately seeking funds to repay money he has embezzled from his employer, 
the Astrologer, and Haffner, also known as El rufián melancólico or the Melancholy Pimp. There follows Erdosain's explanation of how he ran up the debt and the curious reactions of his two interlocutors, in particular with regard to why, when so much money had passed through his hands, he never thought to replace his worn-out boots. It also reveals scepticism about the motivations of revolutionaries: money, power or sex seem to dominate.

The citations, like the many references in Historia del Triste, reveal once again the Chandler-esque literary ambitions of the novel; as Jameson ${ }^{32}$ notes, bookish and cultural references were key to Chandler's self-fashioning as an author and to the development of the crime genre. They also introduce from the outset two keys elements of the plot: escape and embezzlement, since Arellano, disenchanted with the 'orga', aims to use the twice-stolen cash to begin a new life, with his lover, in Europe. Yet, this is not a conventional thriller, for we know the outcome almost from the start. As Risley notes in one of the few reviews of the novel, it begins by removing any suspense, telling us that the protagonist, Arellano, died ten years earlier ${ }^{37}$ (p. 76), in 1974. This use of chronological perspective gives a sense of historical inevitability which underlines the futility of Arellano's attempts at escape and also the militancy that went before it. Risley concludes that 'the novel leaves the strong impression of being unable to take fullest advantage of its rich possibilities', perhaps because of its lack of suspense (76). One might argue that Vázquez Rial falls down where a near contemporary, García Márquez's Crónica de una muerte anunciada (1981), which also reveals to the reader the victim and the perpetrators of its central crime at the very start, triumphs.

La libertad shares many features with Historia del Triste: the same telegraphic prose, with its lack of full-stops and excess of colons, the same in medias res paragraphs, and the same proliferation of literary epigraphs at the start of chapters (Borges, José Eustasio Rivera, T.S. Eliot and others). There are various references to 'los tristes' ${ }^{34}$ (pp. 131-32); there also appears a character by the name of 'Otálora', involved in extortive kidnappings, a near anagram of el Triste's surname, Artola. La libertad ends with a brief coda on Marga's sad situation as a widow. Before that, we are told the circumstances of Artola's death, at the hands of what seem to be two professional or at least skilled and well-armed, killers. He is left mid-thought: 'la bala que le atraviesa la frente es como una prueba de la inutilidad de todos sus esfuerzos, de todos sus deseos, de todos sus' (sic) (145). Whereas el Triste dies with the words 'Patria o Muerte $^{18}$ (p. 227) on his lips (but which no one hears), it seems Arellano has no time for last thoughts, let alone last words.

In contrast to Historia del Triste, though, La libertad is framed as a story told by Joan Romeu, a regular Vázquez Rial protagonist, to Marga. She is now working in a seedy cabaret in Barcelona and seeking answers as to the disappearance of her lover, with whom she had planned to flee to Italy. The narrative is interrupted by Romeu's questions to Marga, as a voiceover to the action of the novel. Meanwhile, its historical digressions are more limited; more space is dedicated to the characters' backgrounds and there is even a strikingly lyrical description of a river, on the border between Argentina and Brazil, that would not be out of place in the short stories of Horacio Quiroga or Rivera's jungle novel, whose quotation begins the chapter in question. Arellano's flight north and in particular his entrance into a rundown ranch-cum-pulpería (bar), reads rather like a geographically inverted rewriting of Borges' short story 'El sur.'

Risley suggests that the novel offers a 'portrayal of the psychological environment of terrorism $(\ldots)$ : the replacement of one's natural personality and the dehumanised detachment of the terrorist and the continual strain to suppress the real self' ${ }^{37}$ (p. 76). In a description of 'el compañero Armando,' told through Arellano's memories, we read of a curious path of a Jewish communist who converts to Catholicism, adopts the telling moniker Pablo, and develops a personal political worldview based on a mixture of Peronist populism, liberation theology and 'resabios talmúdicos'34 (p. 91). This pseudo-philosophy justifies his headlong rush into armed struggle. Armando is one of the many militants who people these novels and whose motives boil down to one of the following: mental disturbance or confusion, low cynicism or bad faith, or, in the case of protagonists such as Romeu or Arellano, mistaken good intentions that eventually give way to disillusionment. Thus, even in what is otherwise 
a more direct, stripped-down novel, Vázquez Rial finds space for his own, very particular readings of Argentine history.

What is more, as in Historia del Triste, Vázquez Rial's novel constantly blurs the line between the armed left and its stated enemies. We see this in the novel's digressions, sections not essential to the plot or the development of central characters. Arellano's escape into Brazil is aided by a former Nazi by the name of Gärtner. The latter has earnt the nickname 'el niñero' or the babysitter, for his lack of compunction in murdering (specifically Jewish) children. Gärtner ferries exiles across the border for money. The narration, with recourse to what looks initially like a criminal record but soon becomes a macabre sketch of the man's crimes, details his entry into Argentina along with other Nazis and a cache of stolen gold and money. It was, we are told, facilitated by a German Embassy representative by the name of Eva Duarte ${ }^{34}$ (pp. 106-7). ${ }^{38}$

Arellano shoots Gärnter, who has eyes rather less keen than those of his double, the mythological ferryman Charon. Risley suggests that 'Gartner incarnates the novel's political message: to stay in power, the regime is willing to create a new genocidal holocaust, eliminating an entire generation, ${ }^{37}$ (p. 76). But Risley's reference to the regime echoes Vázquez Rial's implication that there is no real change of regime either side of the coup of 1976 and that militants like Arellano were unwittingly fighting for and against the same side.

Vázquez Rial claimed that the novel aimed to break the silence about the dictatorship in Argentina. Speaking in 1994, he opined that 'A memoria, en Arxentina, está condenada. Porque, se non é remota, leva irremediablemente á dictadura, e da dictadura ninguén quere falar' ${ }^{16}$ (p. 197). Yet, for a novel published in 1987, it hardly shakes the contemporary consensus about the violence of the 1970s and, indeed, it could even be seen as a step back to the start of the decade. In fact, what Vázquez Rial offers is a noir version of the 'teoría de los dos demonios': the narrator, Romeu, reflects that for Arellano, 'ni los vencedores ni los vencidos que quedan a sus espaldas le parecen hermosos, ni las causas que se le ofrecen le parecen causas justas ${ }^{34}$ (pp. 132-33). This is close to the idea, popularised by the Sabato report of 1984 of the crimes of the dictatorship, that there was an equivalence between the violence of the armed left and state repression (the 'two demons') and that the civilian population was the innocent victim of this violence. The report, entitled Nunca más, was commissioned by the liberal government of Raúl Alfonsín after the return to democracy in 1983, in response to calls for answers as to the fate of the 30,000 disappeared.

There is a further problem with Vázquez Rial's use of history. As he stated in an interview, La libertad de Italia was based on a genuine case, the disappearance of the real Miguel Arellano. He was also a member of the $\operatorname{ERP}^{16}$ (p. 187). Yet, Arellano was not killed by his comrades and did not die in 1974. In fact, Arellano, an electrician and Communist activist, disappeared in 1978 alongside his wife, Mirta Adriana Bai and their young son. ${ }^{39}$ Although the child's grandmother was able to locate the boy, neither Mirta nor Miguel were seen again, both victims of a military hit squad. Thus, the sense of inevitability that the plotting deliberately creates runs up against a historical block, namely, that Arellano's death was not inevitable nor was it at the hands of his comrades in arms. Rather, it required a military coup and subsequent violent repression to occur. Only if one accepts Vázquez Rial's interpretation of the pre- and post-coup situation in Argentina - namely, that the same forces were operating either side of the takeover and that sections of the armed left were front operations - does Arellano's fate in the novel become anything other than a fantasy. This is no small problem for a novel with pretensions not just to be compelling art, but also to offer insight into the past.

\section{Territorios vigilados}

Vázquez Rial revisited the Arellano case in the novel Territorios vigilados (1991, first published 1988). The distinctive features of the two earlier novels are still very much on display and indeed some - not least the levels of sex, violence and alcohol consumption - are intensified. We read the same catalogue of literary references - to Goethe, Hugo, Duras or in the shape of a character by the name of Cambaceres. The protagonist Romeu visits a house in Témperley, owned by the former militant Reclús, whom he holds responsible for Arellano's death. In Arlt's Los siete locos, this is the town 
where the Astrologer has his hideout. Stylistically, again, chapters begin in medias res, sometimes with a conjunction ('y...'). Dialogue plays more of a role and there are fewer historical digressions in the narration. What reflection there is on Argentina's past comes from the mouths of characters, in particular Romeu, who offers an interpretation of recent violent events in conversation with other characters, rather than directly from the narrator. This includes his own theories of the revolution, meditations on his youthful naivety and an insight into his suspicions about Perón ${ }^{19}$ (pp. 128-29). Throughout the novel, there are nods to the history of Argentina. Romeu's first lead comes from a character known as el Grotesco Rosas.

Again, the novel opens with two epigraphs. One is from Machiavelli, from book eight of Istorie Fiorentine, on a failed uprising against the Medici in 1478 and the ultimately unsuccessful attempts to flee by one of the conspirators, Jacopo de' Pazzi. The latter was subsequently captured, tortured and executed, before his corpse was abused in a variety of ways. The second is from Bertolt Brecht, Refugee Conversations, on the need to flee from any country in which there is a great thirst for liberty: in a free country, that thirst does not exist.

Set over a few weeks in March-April 1986, the novel sees Joan Romeu, ex-militant, historian, friend of Arellano and Marga, returning to Buenos Aires to investigate the killing. He has been given a tip off regarding the identity of Arellano's murderer: a German, by the name of Schlemihl. However, this turns out to be a set up: Romeu is being lured back to Buenos Aires so that he too can be killed by a nebulous cabal formed by his ex-comrades, the military and shadowy figures in what one might call Argentina's deep state. Again, the novel features 'la orga', of which Romeu and Arellano had once formed part and its connections to the dictatorship and its continued legacy and networks in newly democratic Argentina. Instead of killing Schlemihl, Romeu joins forces with him to seek out the real instigators, leading to a sequence of gruesome discoveries and the final, bloody showdown from which Romeu emerges victorious and, perhaps surprisingly, scot-free.

Over the course of the investigation - which is less an investigation in the intellectual sense and more a series of confrontations, leads and coincidences - we discover more about Romeu's past and about the militant group of which he and Arellano once formed part. Romeu himself had orders to kill his friend but refused to carry them out. As a result of this disobedience and because of a sense of disillusion shared with Arellano, he left the organisation for exile in Spain. From early in the book onwards, we read of Romeu's 'honour code': 'un código de honor que le impone imprecisas venganzas y el ciego impulso de los actos diarios ${ }^{19}$ (p. 16). He is not a revolutionary because he refuses to take orders (16). Later, he reflects on the clichés of revolutionary language: 'fidelidad', 'solidaridad debida' or 'los compañeros' (39). He pours scorn on members of the 'orga' who changed sides, joining the ranks of the military's torturers and murderers. But much of the vitriol is reserved for the bystanders, those who tried to ignore what was going on around them during the dictatorship. After discovering that his former lover Bianca has been savagely murdered, Romeu guns down the door to the flat opposite and beats the occupant for information. After getting what he can out of the man, Romeu harangues him for his passivity, for having witnessed two raids without a word (a decade earlier, Bianca's husband had disappeared). 'No se podía hablar. Era el proceso...' explains the man. 'El proceso de corrupción de tu conciencia de mierda, querrás decir', replies Romeu ${ }^{19}$ (p. 160).

With that observation, Romeu's position would be close to the one of those commentators, sociologists and activists - the likes of Hugo Vezzetti or Guillermo O'Donnell or the recent volume by David Sheinin - who have highlighted civilian complicity during the dictatorship. Romeu's twist is to assert his own moral superiority over the rest of the populace, imposed through argument and physical force. His is a particular type of vengeance: '(M)i venganza no consiste en cargarme a uno más, sino en conservarme vivo. Eso es lo que les duele, y pienso insistir' ${ }^{19}$ (p. 83). This individualism is one of the causes of his break with militancy: 'Esto es personal. Ya no represento al pueblo' (117). A similar phrase can be found in Historia del Triste: 'lo mío es personal (...) venganza' ${ }^{18}$ (p. 91). In 2004's La capital del olvido, in which once again Romeu returns to Buenos Aires, we read that 'necesitaba contarse a sí mismo en el minúsculo grupo de los que tienen razón'17 (p. 263). 
In an angry exchange after being taken to see the film La historia oficial, Romeu tells Bianca that, even if he is not innocent, he is 'better' than both cazadores (i.e., the military) and conejos (i.e., militants) ${ }^{19}$ (p. 82). Bianca and Romeu discuss the militants' mindsets; in Romeu's assessment, they were hoping to be killed ('no queríamos vivir (...) Los compañeros: estábamos esperando que nos mataran' (68-69)). Vázquez Rial repeats Romeu's claim in a 2007 article: 'Los muertos fueron a la muerte por elección propia, buscando el fin por vía del enfrentamiento con otros psicópatas o sociópatas, militares y civiles, reclutados por la dictadura para ese terrible acting out (sic) que se llevó a cabo en la Argentina de los $70,{ }^{40}$ The militant leadership, meanwhile, were a 'pandilla de inspirados carniceros' 19 (p. 99). Perhaps, the final word of the subject comes from Madán Greván aka Ofelia, the mystic who leads Romeu to the truth: '¿No ves que (Reboratti) es un milico? ¿No ves que ahora somos todos milicos? ¿No ves que lo que hay que cerrar es la boca que da órdenes?' (172). Her theory is a reworking of the 'dos demonios' theory: both cazadores and conejos have adopted a military mindset. This echoes the critique made by Gelman and others in their open letter to the montoneros, ${ }^{27,41}$ but it also continues the theory proposed in Historia del Triste that Montoneros and other armed left groups were covers for the secret services. Reboratti, according to Madán Greván/Ofelia, 'servía a los dos costados'19 (p. 172). Although under-developed as a character, he is presented as something like Romeu's double: schoolmates, then comrades in the party and the 'orga' (174), he is someone who has followed Romeu his whole life. In the final confrontation, he is accompanied by a judge and a navy officer - both of whom Schlemihl kills in what Romeu calls a 'summary execution' (180).

Romeu's interpretation, which the narration does nothing to contradict, seems to be this: when he, Schlemihl and Arellano were members of the 'orga', they did not carry out torture, murder innocent civilians or so forth. The hit squad mopping up after Arellano and on the heels of Romeu, clearly does all this: besides torture and gruesome murders, they even shoot Reclús's dog. The only plausible assumption is that the organisation had been infiltrated at the very top level. As a result, the 'orga' became rotten throughout: 'llegó a haber demasiados puntos de contacto', Romeu suggests ${ }^{19}$ (p. 161). If there are any heroes, they are those who did not turn their coats and who did not turn into 'destripadores' (162): the likes of Schlemihl and Romeu. Even after the death of Reboratti, the conspiracy continues: Reclús's house is burned down, destroying the evidence, and Madán Greván/Ofelia is murdered on the street.

Territorios is a violent novel and also a tragic novel. We read of families destroyed, of torture and murder and of the steady annihilation of Romeu's former comrades. It is a novel of bizarre and grotesque characters. It adds an element not seen so prominently in other novels, namely, characters who believe in the supernatural. Madán Greván/Ofelia presents herself as a 'bruja' and speaks of the counterrevolution as the embodiment of diabolical forces. Romeu believes, if not in the devil, in evil ('el mal' ${ }^{19}$ (p. 174)). In an interview, Vázquez Rial spoke about his own belief in supernatural powers. He stated that 'Eu creo que o irracional, no senso do aínda non racionalizado, forma parte do real ${ }^{16}$ (p. 188). Buenos Aires is something like a ghost town, one that the next generation cannot wait to leave. 'Irme. ¿Qué querés que haga?' responds the young Griselda, the daughter of Romeu's former lover, after they too have been to bed, when asked about her future plans ${ }^{19}$ (p. 43). Elsewhere, Vázquez Rial stated that in 1983 a whole generation, those in their forties, consisted of five categories: 'the disappeared, the exiled, the frightened, those compromised by (...) El Proceso and those who lived in cloud cuckoo land' (28). But at the end, Romeu returns to Spain, where he is able to dispatch Arellano's ghost. The novel ends with him addressing himself in the mirror: he has buried the old Romeu, '(c)on todos los honores' and can start again from zero (211).

The cult of courage, the prestigious literary citations, the lauding of individualism, the superstition: one might suggest echoes of Arturo Jauretche's classification of medio pelo literature in Argentina (1966). Yet, in contrast to Beatriz Guido, the subject of Jauretche's analysis, Vázquez Rial cares little for readers' sensitivities. He adds violence, a style drawn and accentuated from an anything-but-prestigious genre, namely, the hard-boiled, and a very particular reading of history. Nor can one just read these works as camp or kitsch, ('feigned good taste' in Amícola's definition ${ }^{42}$ ). On Chandler, Jameson writes: 'Part of the appeal of Chandler's books for us is a nostalgic one. They are among a whole class of objects we once called "camp",32 (p. 14). There is some nostalgia in Historia del Triste - for the barrio, for certain 
traits of working-class life, though not for the first Peronism, which in the novel seems to offer little benefit to ordinary Argentines. In his historical novels, such as Frontera sur, nostalgia has gone bad.

Territorios vigilados and other works by Vázquez Rial are also about language. Early on, there is a discussion of Romeu's use of the verb ' $\operatorname{coger}^{19}$ (p. 19), obscene to Argentines but ordinary for Romeu. He is called a 'gallego', which he quickly corrects to Catalan. 'Gallego', Galician, is the slang term in Argentina for all Spaniards - in a sense, Romeu is and is not a gallego in Argentina. Elsewhere, in the novel Frontera sur, there are repeated discussions of the use of tú or vos to address the singular second person. In La capital del olvido, we note that Romeu is leista in his use of object pronouns, a Spanish feature rejected by most Argentines ${ }^{17}$ (p. 167). The effect is that Romeu, Arellano and other key characters in Vázquez Rial are cast permanently as outsiders and thus, one might argue, above the fray. If el Triste is an outsider because of his humble origins, a middling character (as stated above), the later heroes remain divorced from the world around them, despite their relatively privileged and rather less middling, upbringings.

This is related to an internationalist view of culture that the author has expounded elsewhere. 'The more overtly 'national' and 'institutional' the features of culture within a culture, the further are its citizens from a culture which signifies human achievement, human control of natural forces and the recognition of the need for liberty. Real culture liberates the person'43 (p. 25), he wrote in a portrait of culture in Argentina in the 1980s and early 1990s. In the same article, he spoke of a 'widening abyss between those who stayed and those who left' (29) during the dictatorship years. Later, in the novel La capital del olvido, we are told of the repugnance that Romeu feels towards 'las identidades colectivas' 17 (p. 263).

Here, we are reminded of other famous foreigners in the detective genre and in particular Raymond Chandler's Marlowe. The 2004 novel, La capital del olvido, begins with what Jameson calls, referring to Chandler, an 'inaugural visit to the wealthy client ${ }^{32}$ (p. 44) as well as a series of overt references to the American's work. ${ }^{44}$ Indeed, La capital del olvido borders on homage, at least in its opening sections (especially to The Long Goodbye). Fredric Jameson's recent study of Chandler becomes relevant and especially because of this question of style. As Jameson observes, 'the detective story represented something more (than) a mere commercial product, furnished for popular entertainment purposes ${ }^{32}$ (p. 1). Chandler's self-perception as a stylist had much to do with his status as an adoptive American, 'already a kind of stylist by force of circumstance' (2). Much the same can be said of the transatlantic Vázquez Rial, for whom style and literary references seem as important as the (often quite basic) stories that he tells; he too cultivates the national-outsider status of his main characters. As Jameson suggests, 'The detective story, as a form without ideological content, without any overt political or social or philosophical point, permits such pure stylistic experimentation' ${ }^{32}$ (p. 2). He continues, 'the empty, decorative event of the murder serves as a way of organizing essentially plotless material into an illusion of movement, in the formally satisfying arabesques of a puzzle unfolding' (3). This allows a sociological approach to crime, much like what we have seen in Vázquez Rial: 'the gangland violence of the American big city is felt as a secret destiny, a kind of nemesis lurking beneath the surface of hastily acquired fortunes, anarchic city growth and impermanent private lives' ${ }^{32}$ (p. 5). Romeu, like Marlowe, in a number of novels 'visits either those places you don't look at or those you can't: the anonymous or the wealthy and secretive' ${ }^{32}$ (p. 7).

However, there is a contrast between the two in the matter of politics. Few national figures appear in Vázquez Rial, except at a distance, sketched in the background sections of, for example, Historia del Triste. Juan Perón, López Rega, Eva Perón and even Ernesto Che Guevara or cultural figures such as Carlos Gardel are treated with scepticism, if not cynicism, whereas in Chandler, 'the national politicians (with occasional stunning examples) seem to be beyond personal self-interest and this lends an automatic prestige to their professional affairs' 32 (p. 10). Jameson adds that a 'kind of reverence attaches to the abstract, a disabused cynicism to the concrete ${ }^{32}$ (p. 10). If there is a reverence in Vázquez Rial's work, it is also to the abstract, but to abstract values, namely, the honour code of characters like Arellano, Romeu or - in his last moments - el Triste. One might compare this with Soriano's No habrá más penas ni olvido (1978), where the local is capable of both great nobility and vicious corruption; Perón 
and the abstract values of 'true' Peronism remain firmly (ironically?) beyond reproach. The role of the middling character in the historical novel was to take us close to great men and historical events, but with a sense of movement through the classes, while providing a protagonist with whom the reader might associate. Vázquez Rial's approach, instead, creates distance from the centres of power and the sites of the powerful. Rather, the focus is on the shadowy conspiratorial networks near to or behind, what can be observed of the powerful in action. The form itself may be without ideological content, but Vázquez Rial has a political point to make and works the form accordingly.

Vázquez Rial's novels raise a further question, that of the role of the detective. Romeu acts as a detective, investigating murders and other crimes in Territorios vigilados and La capital del olvido, but, as should be clear, he is not a conventional one. Novels such as La libertad de Italia or Historia del Triste deal with crime but have no detective. The former has no mystery, the latter has a series of them, the most important of which is who is ultimately responsible for el Triste's orders.

Jameson suggests that, 'one of Chandler's originalities (...) was the attempt to substitute some other kind of motivation for the standard financial or materialist one'32 (p. 43). The question of motivation remains a problem in Vázquez Rial. For some characters, money is clearly a driver. For the likes of el Triste and Arellano, money is a tool to achieve freedom. For others, like Reclús or Reboratti, the motivation is unclear. Are they cynics or psychopaths? Politics comes to stand in for their absence of any clear motive. Vázquez Rial is interested not so much in the system or the state, as in the secret plots that operate near it, behind it or alongside it.

This is closely linked to Vázquez Rial's attitude to history. As Dölle observes in a review of his Las dos muertes de Gardel, 'A pesar de la abundancia de datos históricos, el autor pretende descubrir una verdad más profunda refiriéndose a la condición humana' ${ }^{45}$ (p. 123). The 'a pesar' is a telling phrase; later, Dölle notes that the author makes use of 'datos históricos, no siempre fehacientes' (124). Young ${ }^{21}$ (pp. 505, 512-13) reads Vázquez Rial's work - specifically the novel Los últimos tiempos - in a general post-modern framework, in which characters and structure question the grand narratives of Marx, Freud, et al. In the novel, Romeu even visits Marx's grave, crying over the crimes committed in the latter's name. But one thing is to question grand narratives, another is to replace them with the conspiratorial histories that underlie the action of all these novels. As Jameson observes, Chandler's novels have a dual structure, with an objective and a subjective form ${ }^{32}$ (p. 22). 'The detective no longer inhabits the atmosphere of pure thought' (24), the 'trail of bloodshed is a false scent' (25), 'For the discovery of the criminal here is only half of a more complicated revelation' (27). For Vázquez Rial, this revelation is the opportunity to fill the 'empty form' of the detective fiction with an ideological content of his own devising, namely, a conspiratorial view of recent Argentine history.

In a recent study, Jovan Byford characterises the conspiracy theory with regard to three features: 'the view of the conspiracy as the motive force in history, the approach to evidence (or the absence of it) and the conspiracy theory's essential irrefutability ${ }^{\prime 6}$ (p. 32). Byford distinguishes between 'total' theories about conspiracies and what he describes as the acknowledgment of 'multiple' unrelated plots ${ }^{46}$ (p. 33). Whereas it is sensible to suppose that 'the size and complexity of a conspiracy and its level of nefariousness will be inversely proportional to its chances of success' (33), the 'total' conspiracy theorist thinks quite the opposite: it is the very totality or huge scale, of the plot, that destines it for triumph. Dentith agrees on this point: there is a difference between conspiracy theories and 'total conspiracy theories'47. 'Some theories about conspiracies can be warranted (and) conspiratorial activity is more common than most people think' (172-73). A key reference for studies of conspiracy theories is Richard Hofstadter's essay, based on a 1963 lecture, 'The Paranoid Style in American Politics.' Hofstadter, writing in the context of but not referring solely to the resurgence of the American far right, describes a style of discourse characterised by 'heated exaggeration, suspiciousness and conspiratorial fantasy 48 (p. 3). Exponents of the paranoid style 'regard a 'vast' or 'gigantic' conspiracy as the motive force in historical events' (29). The paranoid thus suffers doubly from history, 'since he is afflicted not only by the real world, with the rest of us, but by his fantasies as well' (40). Aaronovitch explains that the political history of a region may well explain people's propensity for believing in conspiracies. He gives the example of the Middle East and adds that 'it would be surprising if many Latin Americans, subject 
for fifty years to a sequence of military takeovers, were not of the same mind ${ }^{49}$. Conspiracy theories and in particular a grand conspiracy theory about the left in Argentina, are central to Vázquez Rial's novels.

Andermann continues his assessment of contemporary right-wing writing in Argentina with observations on works by Luis Majul and Nelson Castro: 'What's so great about conspirational (sic) discourse (...) is that it is completely reality-proof' ${ }^{14}$ (p. 13). The conspiratorial mindset means that one can always impugn the motives of political opponents, yet reality - the conditions in which people have to live and work - becomes irrelevant. These novels from the late 1980s, then, not only presage Vázquez Rial's own turn to the right, but also other conspiratorial fictions, like Jorge Fernández Díaz's bestselling El puñal (2014).

Picking up Andermann's prompt, what can Cultural Studies as a discipline or literary studies more broadly, do with novels such as these? They are important because they add several new dimensions to Pepper's history of the genre and re-contextualise Jameson's work on the hard-boiled. Yet, at the same time, they are underpinned by a conspiratorial, reactionary and reality-proof reading of Argentina's recent history. The conspiracy theorist reasons thus: the less evidence there is to support my theories or the more evidence there is to contradict them, then the more likely they are to be true. They resolve individual dramas in the shape of acts of heroism, ending either in a certain tragic dignity (Artola, Arellano) or in a triumphant escape (Romeu) and leave, unresolved, hanging in the air, a theory of recent Argentine history that damns whole swathes of the political left as dangerous or deluded. Morally and physically, only Romeu - in biography and opinions, a transparent cypher for the author - survives. This individualism, paradoxically, is precisely what Vázquez Rial condemned about the violence of the 1970s. Yet, at the same time, something in these novels escapes Vázquez Rial's ideology and they are at their most successful when they tell stories that the author himself, especially in his later career, might find politically uncomfortable: the reader cannot but help feel human sympathy for el Triste, and, while we come to despise the hit squads and turncoats of Italia and Territorios, the conspiracy theories never feel as compelling as the action of the novels. The history they want to recount is never as convincing as the human stories they relate.

Ideologically, these novels are no more convincing than Vázquez Rial's vitriolic offerings for liberal blogs and online newspapers. However, in their moments of doubt, in their uncertainties, they become interesting as works of political fiction. In answer to the above question that Larsen posed of Vargas Llosa, of whether we can speak here of an artistic integrity that chooses, over ideology, the "story that has begun to tell itself', in the best moments of Historia del Triste or perhaps in Romeu's moments of doubt in Territorios vigilados, then yes, we might. The novels will long outlive his pamphleteering; perhaps they already have.

\section{Declarations and conflict of interests}

The author declares no conflicts of interest.

\section{Notes}

${ }^{1}$ An earlier version of this paper was presented at the 2017 Radical Americas Conference, Institute of the Americas, University College London. I am grateful to William Booth and to the other panel and audience members for their contributions.

${ }^{2}$ See e.g., Close (2008); Giardinelli (1984); Padura (2000); Simpson (1990). The pioneering study is Yates (1964). On the specific case of Argentina, see Ponce (2001) and Lafforgue and Rivera (1996).

${ }^{3}$ See Wood (2016); see also the DPhil thesis by Beard (2015).

${ }^{4}$ Pepper, Andrew. 2016. Unwilling Executioner: Crime Fiction and the State. Oxford: Oxford University Press.

${ }^{5}$ In some later novels, his surnames appear hyphenated.

${ }^{6}$ For full details of his trajectory, see Noya and Somalo (2008) and also Vázquez Rial's 2007 article ('Locos y malvados'). There is a lack of agreement over the dates of his exile. His obituary in Revista $\tilde{N}$, Clarín's cultural supplement, gives three possible dates, between 1968 and 1974. In an interview with González Gómez, he stated that he first came to Spain in 1970 and travelled around Europe, before 
returning to Argentina 'onde cría que tiña unha función que cumprir' and realising his error, leaving the country and settling for good in Barcelona in 1974 (González Gómez and Vázquez Rial 1994, p. 192). The year 1974 is also the date given in Noya and Somalo (2008). On the history of the ERP, which in the mid-1970s split and partly fused with Montoneros, see Seoane (2009); on the armed left in Argentina more widely, see Feinmann (2011) and James (1988).

${ }^{7}$ Like another innovator in the crime genre, the Cuban Leonardo Padura Fuentes, Vázquez Rial has also penned a number of works of popular history.

${ }^{8}$ Vázquez Rial, Horacio. 2001. Lo multicultural como mitología y como coartada del racismo. Scripta nova. Available online: http://www.ub.edu/geocrit/sn-94-29.htm (accessed on 15 March 2017).

9 Vázquez Rial, Horacio. 2011. La Bonafini y compañía. Libertad Digital. Available online: http://www.libertaddigital.com/opinion/exteriores/la-bonafini-y-compania-1276239125.html (accessed on 15 March 2017).

10 Vázquez Rial, Horacio. 2010. Ruego a Dios que no se reencarne Kirchner. Libertad Digital. Available online: http://www.libertaddigital.com/opinion/horacio-vazquez-rial/ruego-a-dios-que-no-sereencarne-56896/ (accessed on 15 March 2017).

${ }^{11}$ El Ciervo. 2003. Review of La izquierda reaccionaria by Horacio Vázquez-Rial. El Ciervo 52: 43.

12 Noya, Mario and Javier Somalo. 2008. Vázquez-Rial: Por qué Dejó de ser de Izquierdas. Avaiable online: https://www.clublibertaddigital.com/ilustracion-liberal/53/vazquez-rial-por-que-dejode-ser-de-izquierdas-mario-noya-y-javier-somalo.html (accessed on 14 December 2017).

${ }^{13}$ Mandel, Ernst. 1984. Delightful Murder: A Social History of the Crime Story. London: Pluto, p. 134.

${ }^{14}$ Andermann, Jens. 2016. It's the Ideology, Stupid! In Macri's Argentina: A Reportage. Journal of Latin American Cultural Studies 25: 7-17.

${ }^{15}$ Larsen, Neil. 2000. Mario Vargas Llosa: The Realist as Neo-Liberal. Journal of Latin American Cultural Studies 9: 155-79.

${ }^{16}$ Gómez, Xesús González and Horacio Vázquez Rial. 1994. Entrevista con Horacio Vázquez Rial. Grial 32: 181-97.

${ }^{17}$ Vázquez Rial, Horacio. 2004. La capital del olvido. Madrid: Alianza.

${ }^{18}$ Vázquez Rial, Horacio. 1987a. Historia del Triste. Barcelona: Círculo de lectores.

${ }^{19}$ Vázquez Rial, Horacio. 1991. Territorios vigilados. Barcelona: Plaza \& Janés.

${ }^{20}$ Black, Joel. 1991. The Aesthetics of Murder. A Study in Romantic Literature and Contemporary Culture. Baltimore and London: Johns Hopkins University Press.

${ }^{21}$ Young, Richard A. 1994. Brave New Worlds. Horacio Vázquez Rial's Los últimos tiempos. Revista Canadiense de Estudios Hispánicos 18: 503-14.

${ }^{22}$ Vallese is widely regarded as Argentina's first 'disappeared.' According to a report in Página/12, one of the men actually responsible for his disappearance, Juan Fiorillo, went on to form part of the Triple A and to carry out further acts of kidnap and torture in La Plata (Página/12, 'Murió el asesino...' 2008).

${ }^{23}$ For an insightful analysis into the logic of this crime, see Feinmann (2011, pp. 64-67).

${ }^{24}$ Foster, David William. 1987. Review of Historia del Triste by Horacio Vázquez Rial. World Literature Today 61: 425.

${ }^{25}$ Liberman Isod, Mónica. 1987. Review of Historia del Triste by Horacio Vázquez Rial. Hispamérica 16: $230-33$.

${ }^{26}$ Space does not permit a fuller exploration of the historical novel in Latin America, but some brief observations are required. As Jameson puts it, 'The historical novel as a genre cannot exist without [the] dimension of collectivity, which marks the drama of the incorporation of individual characters into a greater totality and can alone certify the presence of History as such' (Jameson 2013, p. 267). It is clear that for $e l$ Triste, this collectivity is at best an illusion. Of relevance to Vázquez Rial's style, Jameson claims that 'the historical novel was traditionally a contract whereby we agreed to tolerate a certain number of fictional characters and actions within a framework equally agreed to be factual' (298). One might ask if our author is pushing that level of tolerance. The last two decades of the last century and the first of this saw a boom in studies of the historical novel, in particular of the Latin American historical novel, See e.g., Barrientos (2001), the collection edited by Balderston (1986), Parkinson Zamora (1997), 
Menton (1993) and the two volumes by Larsen (Larsen 1995 and especially Larsen 2001). Not on Latin America, but highly influential and offering a different perspective on the postmodern to Jameson, is Hutcheon (1988). Anderson coined the term 'meta-historical fiction' to refer to a tendency that emerged fundamentally in Latin America and in particular with the publication of Carpentier's El reino de este mundo (Anderson 2011, p. 28).

${ }^{27}$ Gillespie, Richard. 1982. Soldiers of Perón. Argentina's Montoneros. Oxford: Clarendon, p. 266.

${ }^{28}$ Amorín, José. 2006. Montoneros. La buena historia. Buenos Aires: Catálogos, pp. 243-53.

${ }^{29}$ Calveiro, Pilar. 2005. Política y/o violencia. Una aproximación a la guerrilla de los años 70 . Buenos Aires: Verticales/Norma.

${ }^{30}$ Gamerro, Carlos. 2006. La aventura de los bustos de Eva. Barcelona: Belacqva.

${ }^{31}$ Gamerro, Carlos. 2011. Un yuppie en la columna del Che Guevara. Buenos Aires: Edhasa.

32 Jameson, Fredric. 2016. Raymond Chandler. The Detections of Totality. London: Verso.

${ }^{33}$ See Bollig (2011, chp. 2).

${ }^{34}$ Vázquez Rial, Horacio. 1987b. La libertad de Italia. Barcelona: Destino.

${ }^{35}$ Cervantes, Miguel de. 2009. Novelas ejemplares II. Edited by Harry Sieber. Madrid: Cátedra, p. 45.

${ }^{36}$ Arlt, Roberto. 1998. Los siete locos. Madrid: Cátedra, p. 109.

${ }^{37}$ Risley, William R. 1989. Review of La libertad de Italia. World Literature Today 63: 75-76.

38 The story of the Peróns' links to Nazi Germany has been told more than once, starting with Silvano Santander's polemic, published in 1953 in Uruguay, Técnica de una traición. Juan D. Perón y Eva Duarte. Agentes del nazismo en la Argentina. Arturo Jauretche penned an energetic rebuttal, Los profetas del odio, in 1957. More recently, the story has been fleshed out by Uki Goñi (2003). Argentina was not the only country to offer haven to former Nazis: Operation Paperclip was the name of the US programme of recruiting German scientists, including members of the Nazi party, for Cold War weapons research; nor was the Perón administration alone in facilitating escape: Steinacher (2011) has written of the role of both the Vatican and the Red Cross in the 'ratlines' of the 1940s.

39 See the testimony of Nya Quesada at http://catalogo.memoriaabierta.org.ar/cgi-bin/koha/opacdetail.pl?biblionumber=32021 and also record 999 at http://www.desaparecidos.org/GrupoF/des/a.html, MIGUEL ISIDRO ARELLANO, which reads thus: '36 años. Casado. Argentino. Electricista. Desaparecido el: 12/5/78, No.CONADEP: 287. Fue secuestrado en CAPITAL [... ]

No hay testimonio de su paso por un C.C.D.' [centro clandestino de detención].'

40 Vázquez Rial, Horacio. 2007. Locos y malvados. Libertad Digital. Available online: http://www. libertaddigital.com/opinion/ideas/locos-y-malvados-1276233989.html (accessed on 15 March 2017).

${ }^{41}$ Bollig, Ben. 2011. Modern Argentine Poetry. Displacement, Exile, Migration. Cardiff: UWP, p. 65.

${ }^{42}$ Amícola, José. 2000. Camp y posvanguardia. Buenos Aires: Paidós, p. 99.

43 Vázquez Rial, Horacio. 1993. The Crisis of National Culture. In Argentina in the Crisis Years (1983-1990). Edited by Colin M. Lewis and Nissa Torrents. London: Institute of Latin American Studies, pp. 24-34.

${ }^{44}$ On this novel, see Bollig (2006).

45 Dölle, Susanne. 2003. Review of Las dos muertes de Gardel by Horacio Vázquez Rial. Hispamérica 32: 123-24.

46 Byford, Jovan. 2011. Conspiracy Theories. A Critical Introduction. Basingstoke: Palgrave Macmillan.

47 Dentith, Matthew R. X. 2014. The Philosophy of Conspiracy Theories. Basingstoke: Palgrave Macmillan, p. 17.

${ }^{48}$ Hofstadter, Richard. 1965. The Paranoid Style in American Politics. In The Paranoid Style in American Politics and Other Essays. New York: Knopf, pp. 3-40.

${ }^{49}$ Aaronovitch, David. 2009. Voodoo Histories. London: Jonathan Cape, p. 8.

\section{References}

Aaronovitch, David. 2009. Voodoo Histories. London: Jonathan Cape.

Amícola, José. 2000. Camp y posvanguardia. Buenos Aires: Paidós. 
Amorín, José. 2006. Montoneros. La buena historia. Buenos Aires: Catálogos.

Andermann, Jens. 2016. It's the Ideology, Stupid! In Macri's Argentina: A Reportage. Journal of Latin American Cultural Studies 25: 7-17.

Anderson, Perry. 2011. From Progress to Catastrophe. London Review of Books 28: 24-28.

Arlt, Roberto. 1998. Los siete locos. Madrid: Cátedra.

Balderston, Daniel, ed. 1986. The Historical Novel in Latin America: A Symposium. Gaithersburg: Ediciones Hispamérica, New Orleans: Roger Thayer Stone Center for Latin American Studies, Tulane University Press.

Barrientos, Juan José. 2001. Ficción-historia: la nueva novela histórica Hispanoamericana. Mexico: UNAM. Beard, Alex. 2015. Narconovela: Four Case Studies of the Representation of Drug Trafficking in Mexican Fiction. Ph.D. thesis, University of Oxford, Oxford, UK.

Black, Joel. 1991. The Aesthetics of Murder. A Study in Romantic Literature and Contemporary Culture. Baltimore and London: Johns Hopkins University Press.

Bollig, Ben. 2006. Violence without Reason: On Argentine Short Stories. Journal of Iberian and Latin American Studies 12: 79-90.

Bollig, Ben. 2011. Modern Argentine Poetry. Displacement, Exile, Migration. Cardiff: UWP.

Byford, Jovan. 2011. Conspiracy Theories. A Critical Introduction. Basingstoke: Palgrave Macmillan.

Calveiro, Pilar. 2005. Política y/o violencia. Una aproximación a la guerrilla de los años 70 . Buenos Aires: Verticales/Norma.

Cervantes, Miguel de. 2009. Novelas ejemplares II. Edited by Harry Sieber. Madrid: Cátedra.

Close, Glen S. 2008. Contemporary Hispanic Crime Fiction: A Transatlantic Discourse on Urban Violence. New York: Palgrave Macmillan.

Dentith, Matthew R. X. 2014. The Philosophy of Conspiracy Theories. Basingstoke: Palgrave Macmillan. Dölle, Susanne. 2003. Review of Las dos muertes de Gardel by Horacio Vázquez Rial. Hispamérica 32: 123-24.

Domínguez, Mignon. 1996. Historia, ficción y metaficción en la novela latinoamericana contemporánea. Buenos Aires: Corregidor.

El Ciervo. 2003. Review of La izquierda reaccionaria by Horacio Vázquez-Rial. El Ciervo 52: 43.

El Ciervo. 2004. Review of La capital del olvido by Horacio Vázquez-Rial. El Ciervo 53: 42.

Feinmann, José Pablo. 2011. La sangre derramada. Ensayo sobre la violencia política. Buenos Aires: Booket.

Foster, David William. 1987. Review of Historia del Triste by Horacio Vázquez Rial. World Literature Today 61: 425.

Gamerro, Carlos. 2006. La aventura de los bustos de Eva. Barcelona: Belacqva.

Gamerro, Carlos. 2011. Un yuppie en la columna del Che Guevara. Buenos Aires: Edhasa.

Giardinelli, Mempo. 1984. El género negro. Mexico: UAM, vol. 2.

Gillespie, Richard. 1982. Soldiers of Perón. Argentina's Montoneros. Oxford: Clarendon.

González Echevarría, Roberto. 1990. Myth and Archive: A Theory of Latin American Narrative. Cambridge: Cambridge University Press.

Gómez, Xesús González, and Horacio Vázquez Rial. 1994. Entrevista con Horacio Vázquez Rial. Grial 32: 181-97.

Goñi, Uki. 2003. The Real Odessa: How Péron Brought the Nazi War Criminals to Argentina. London: Granta. Hofstadter, Richard. 1965. The Paranoid Style in American Politics. In The Paranoid Style in American Politics and Other Essays. New York: Knopf, pp. 3-40.

Hutcheon, Linda. 1988. A Poetics of Postmodernism: History, Theory, Fiction. London: Routledge.

James, Daniel. 1988. Resistance and Integration. Peronism and the Argentine Working Class. Cambridge: Cambridge University Press.

Jameson, Fredric. 2013. The Antinomies of Realism. London: Verso.

Jameson, Fredric. 2016. Raymond Chandler. The Detections of Totality. London: Verso.

Jauretche, Arturo. 1984. El medio pelo en la sociedad argentina. Buenos Aires: Peña Lillo.

Lafforgue, Jorge, and Jorge B. Rivera. 1996. Asesinos de papel. Ensayos sobre narrativa policial. Buenos Aires: Colihue. 
Larsen, Neil. 1995. Reading North by South: On Latin American Literature, Culture and Politics. Minneapolis: Minnesota University Press.

Larsen, Neil. 2000. Mario Vargas Llosa: The Realist as Neo-Liberal. Journal of Latin American Cultural Studies 9: 155-79.

Larsen, Neil. 2001. Determinations: Essays on Theory, Narrative and Nation in the Americas. London: Verso.

Liberman Isod, Mónica. 1987. Review of Historia del Triste by Horacio Vázquez Rial. Hispamérica 16: 230-33.

Lukács, György. 1962. The Historical Novel. Translated by Hannah Mitchell, and Stanley Mitchell. London: Merlin.

Mandel, Ernst. 1984. Delightful Murder: A Social History of the Crime Story. London: Pluto.

Menton, Seymour. 1993. Latin America's New Historical Novel. Austin: Texas.

Noya, Mario, and Javier Somalo. 2008. Vázquez-Rial: Por qué Dejó de ser de Izquierdas. Available online: https://www.clublibertaddigital.com/ilustracion-liberal/53/vazquez-rial-por-que-dejo-deser-de-izquierdas-mario-noya-y-javier-somalo.html (accessed on 14 December 2017).

O'Donnell, Guillermo. 1997. Contrapuntos: ensayos escogidos sobre autoritarismo y democratización. Buenos Aires: Paidós.

Padura Fuentes, Leonardo. 2000. Modernidad, posmodernidad y novela policial. La Habana: Unión.

Página/12. 2008. Murió el asesino de Felipe Vallese. Available online: https://www.pagina12.com.ar/ diario/elpais/1-103854-2008-05-09.html (accessed on 22 February 2017).

Parkinson Zamora, Lois. 1997. The Usable Past: The Imagination of History in Recent Fiction of the Americas. Cambridge: Cambridge University Press.

Pepper, Andrew. 2016. Unwilling Executioner: Crime Fiction and the State. Oxford: Oxford University Press. Ponce, Néstor. 2001. Diagonales del Género. Paris: Ed. du temps.

Revista N. 2012. Murió en Madrid el Escritor Argentino Horacio Vázquez-Rial. Available online: http://www.revistaenie.clarin.com/literatura/murio-horacio-vazquez-rial_0_H1FF8ee3Pmx.html (accessed on 14 February 2017).

Risley, William R. 1989. Review of La libertad de Italia. World Literature Today 63: 75-76.

Seoane, María. 2009. Todo o nada. La historia secreta y la historia pública del jefe guerrillero Mario Roberto Santucho. Buenos Aires: Debolsillo.

Sheinin, David. 2012. Consent of the Damned: Ordinary Argentinians in the Dirty War. Gainesville: University Press of Florida.

Sigal, Silvia, and Eliseo Verón. 1986. Perón o muerte. Los fundamentos discursivos del fenómeno peronista. Buenos Aires: Legasa.

Simpson, Amelia. 1990. Detective Fiction from Latin America. Rutherford: Farleigh Dickinson University Press.

Steinacher, Gerald. 2011. Nazis on the Run: How Hitler's Henchmen Fled Justice. Oxford: Oxford University Press.

Vázquez Rial, Horacio. 1987a. Historia del Triste. Barcelona: Círculo de lectores.

Vázquez Rial, Horacio. 1987b. La libertad de Italia. Barcelona: Destino.

Vázquez Rial, Horacio. 1991. Territorios vigilados. Barcelona: Plaza \& Janés.

Vázquez Rial, Horacio. 1993. The Crisis of National Culture. In Argentina in the Crisis Years (1983-1990). Edited by Colin M. Lewis and Nissa Torrents. London: Institute of Latin American Studies, pp. 24-34.

Vázquez Rial, Horacio. 1994. Frontera Sur. Madrid: Alfaguara.

Vázquez Rial, Horacio. 2001. Lo multicultural como mitología y como coartada del racismo. Scripta nova. Available online: http://www.ub.edu/geocrit/sn-94-29.htm (accessed on 15 March 2017).

Vázquez Rial, Horacio. 2002. El enigma argentino (descifrado para españoles). Barcelona: Ediciones B. Vázquez Rial, Horacio. 2004. La capital del olvido. Madrid: Alianza.

Vázquez Rial, Horacio. 2005. La imagen de Iberoamérica en las izquierdas europeas. Cuadernos de Pensamiento Crítico 5: 97-108. 
Vázquez Rial, Horacio. 2007. Locos y malvados. Libertad Digital. Available online: http://www.libertaddigital.com/opinion/ideas/locos-y-malvados-1276233989.html (accessed on 15 March 2017).

Vázquez Rial, Horacio. 2009. Perón ha muerto. ÂąViva Perón! Libertad Digital. Available online: http://www.libertaddigital.com/opinion/exteriores/peron-ha-muerto-viva-peron-1276236748.html (accessed on 15 March 2017).

Vázquez Rial, Horacio. 2010. Ruego a Dios que no se reencarne Kirchner. Libertad Digital. Available online: http://www.libertaddigital.com/opinion/horacio-vazquez-rial/ruego-a-dios-queno-se-reencarne-56896/ (accessed on 15 March 2017).

Vázquez Rial, Horacio. 2011. La Bonafini y compañía. Libertad Digital. Available online: http://www.libertaddigital.com/opinion/exteriores/la-bonafini-y-compania-1276239125.html (accessed on 15 March 2017).

Vázquez Rial, Horacio. A dónde ha ido a parar la literatura comprometida. Club Libertad Digital. Undated. Available online: http://www.clublibertaddigital.com/ilustracion-liberal/24/a-donde-haido-a-parar-la-literatura-comprometida-horacio-vazquez-rial.html (accessed on 15 March 2017).

Vezzetti, Hugo. 2002. Pasado y presente: guerra, dictadura y sociedad en la Argentina. Buenos Aires: Siglo XXI.

Wood, Tony. 2016. Fue el estado. London Review of Books. Available online: https://www.lrb.co.uk/v38/ n11/tony-wood/fue-el-estado (accessed on 16 March 2017).

Yates, Donald A. 1964. El cuento policial latinoamericano. Mexico: Andrea.

Young, Richard A. 1994. Brave New Worlds. Horacio Vázquez Rial's Los últimos tiempos. Revista Canadiense de Estudios Hispánicos 18: 503-14. 